\title{
The importance of waterborne disease outbreak surveillance in the United States
}

\author{
Gunther Franz Craun \\ Gunther F. Craun \& Associates, Staunton, Virginia, USA
}

\begin{abstract}
Analyses of the causes of disease outbreaks associated with contaminated drinking water in the United States have helped inform prevention efforts at the national, state, and local levels. This article describes the changing nature of disease outbreaks in public water systems during 1971-2008 and discusses the importance of a collaborative waterborne outbreak surveillance system established in 1971. Increasing reports of outbreaks throughout the early 1980s emphasized that microbial contaminants remained a health-risk challenge for suppliers of drinking water. Outbreak investigations identified the responsible etiologic agents and deficiencies in the treatment and distribution of drinking water, especially the high risk associated with unfiltered surface water systems. Surveillance information was important in establishing an effective research program that guided government regulations and industry actions to improve drinking water quality. Recent surveillance statistics suggest that prevention efforts based on these research findings have been effective in reducing outbreak risks especially for surface water systems.
\end{abstract}

Key words: drinking waters, epidemiology, surveillance systems.

Riassunto (L'importanza della sorveglianza delle epidemie delle patologie trasmesse con le acque negli Stati Uniti). L'analisi delle cause delle epidemie di malattie associate con l'acqua potabile contaminata negli Stati Uniti ha contribuito ad indirizzare le misure di prevenzione a livello nazionale, di stato e locale. Questo articolo descrive i cambiamenti nella natura delle epidemie di malattie nei sistemi idrici pubblici fra il 1971 e il 2008 e discute l'importanza del sistema di sorveglianza delle epidemie associate all'acqua stabilito nel 1971, in un contesto di collaborazione. Un crescente numero di notifiche sulle epidemie attraverso i primi anni 80 aveva sottolineato l'importanza dei microrganismi patogeni nelle acque potabili. Le indagini sulle epidemie hanno permesso di identificare gli agenti eziologici responsabili e le deficienze nei trattamenti e nella distribuzione delle acque potabili, specialmente il rischio elevato associato con sistemi che utilizzavano acque superficiali non filtrate. Le informazioni derivanti dalla sorveglianza sono state importanti per stabilire programmi efficaci di ricerca per indirizzare i regolamenti governativi e le azioni industriali allo scopo di migliorare la qualità delle acque potabili. Statistiche recenti sui dati della sorveglianza suggeriscono che le azioni di prevenzione basate sui risultati di queste ricerche sono state efficaci nel ridurre i rischi di epidemie nei sistemi idrici pubblici.

Parole chiave: acque potabili, epidemiologia, sistemi di sorveglianza.

\section{INTRODUCTION}

Statistics on disease outbreaks associated with contaminated drinking water in the United States have been collected and analyzed for various time periods since 1920 [1-6]. These analyses have informed research, regulatory, and industry actions to improve drinking water quality and reduce waterborne disease risks. For example, the causes of outbreaks reported during 1961-1970 [4] was deliberated during Congressional committee hearings [7], contributing to the passage of the Safe Drinking Water Act $[8,9]$. This [4] also led to a partnership between the US Environmental Protection Agency (EPA) and Centers for Disease Control and Prevention (CDC) to improve the detection, investigation, and report- ing of waterborne outbreaks. The partnership has continued since 1971 with the periodic publication of outbreak statistics associated with drinking and recreational water, the most recent of which are for 2007-2008 [10, 11]. In this article, the Author focuses on the changing causes of outbreaks in public water systems during the past 38 years to illustrate the importance of waterborne disease surveillance.

\section{WATERBORNE DISEASE OUTBREAK SURVEILLANCE}

Public health agencies or health departments in the states, US territories, and localities have primary responsibility for detecting and investigating water- 
borne outbreaks, and during an outbreak investigation, they can request epidemiologic, environmental health, engineering, and laboratory assistance from the EPA and CDC. As part of the surveillance system, outbreak information is voluntarily reported to the CDC. This information includes characteristics of the outbreaks (e.g., etiology, number of cases, illness severity, location), epidemiologic data (e.g., attack rates, vehicle-specific risks), and results from environmental and engineering investigations (e.g., water quality data, contamination sources, adequacy of disinfection and other water treatment deficiencies).

The outbreak reports are evaluated by EPA and CDC personnel to determine whether the epidemiologic evidence is sufficient to implicate water as the probable source of illness. Outbreaks with limited environmental data are included in the surveillance database, but outbreaks that lack necessary epidemiologic data are not. Single cases of chemical or toxin poisonings may be included if drinking water exposure is well documented. Additional information about the surveillance system and criteria for evaluating outbreak reports is available in the most recently published surveillance summary [10].

The surveillance system contains information for 953 outbreaks associated with contaminated drinking water during 1971-2008; 88\% (no. $=834$ ) were associated with water intended for drinking. The remaining outbreaks were associated with water not intended for drinking (no. = 81) and water of unknown intent (no. $=38$ ). Legionellosis outbreaks associated with contaminated drinking water were not systematically included in the surveillance system until 2001; however, outbreaks that occurred before 2001 were recently added to the database after a thorough search of CDC and state health department records [10].

This article considers only those outbreaks reported in public water systems. Of the 834 outbreaks associated with water intended for drinking, $733(88 \%)$ were reported in public water systems; $12 \%$ were associated with individual water systems $($ no. $=88)$ and bottled or bulk water (no. $=13$ ). A public system is defined as either a community or non-community system that provides drinking water through a distribution system with at least 15 service connections or that regularly serves at least 25 persons [12]. Community systems serve the same persons year round; non-community water systems serve the public but do not serve the same persons year round. Of the 152979 public water systems in the United States, $34 \%$ are community systems and $66 \%$ are non-community systems [12]. Community systems serve $77 \%$ of the US population with $70 \%$ of this population supplied by systems that use surface water [12].

\section{DRINKING WATER REGULATIONS}

The Safe Drinking Water Act of 1974 and its subsequent 1986 and 1996 amendments authorized the EPA to set national standards to protect public drinking water and its sources against naturally occurring or man-made contaminants $[9,13,14]$. These standards include health-based maximum levels for microbiologic, chemical, and other contaminants in drinking water and water treatment performance criteria for their removal or inactivation. The EPA regulations apply only to public water systems. To help interpret the outbreak statistics reported in this article, it is necessary to be familiar with the various regulations and when they were promulgated (Table 1). Regulations that protect against waterborne exposure to pathogens include the Surface Water Treatment Rule and its amendments [15-21], the Total Coliform Rule [2225], and the Ground Water Rule [26, 27]. In addition, the EPA periodically publishes a list of contaminants that will be evaluated for potential regulatory action; Legionella pneumophila was included in the 2009 contaminant list [28, 29].

The Surface Water Treatment Rule and its amendments specify water-treatment techniques (e.g., filtration and disinfection), monitoring, and performance criteria for systems that use surface water sources or ground water sources that are under the direct influence of surface water. The 1989 rule required these systems to reduce the source water concentration of Giardia cysts and viruses by at least $99.9 \%$ and $99.99 \%$, respectively [15]. In addition, a detectable disinfectant residual must be maintained throughout the entire distribution system, and filtration performance must be assured by monitoring turbidity levels. The 1998 rule specified 99\% removal of Cryptosporidium oocysts for filtered systems that serve 10000 or more people [16]. It also required more stringent turbidity criteria and the monitoring of individual filters.

Table 1 | National regulatory requirements for microbial contaminants

\section{Regulation}

Total Coliform Rule

Surface Water Treatment Rule

Interim Enhanced Surface Water Treatment Rule

Filter Backwash Recycling Rule

Long Term 1 Enhanced Surface Water Treatment Rule

Long Term 2 Enhanced Surface Water Treatment Rule

Ground Water Rule

$\begin{array}{ll}\text { Date promulgated } & \text { Compliance date } \\ \text { June } 1989 & \text { December } 1990 \\ \text { June } 1989 & \text { December } 1990 \\ \text { December } 1998 & \text { January } 2002 \\ \text { June } 2001 & \text { June 2004-2006 } \\ \text { January 2002 } & \text { January 2003 } \\ \text { January 2006 } & \text { January 2009-2011 } \\ \text { January 2007 } & \text { December 2009 }\end{array}$


The 2002 rule extended Cryptosporidium removal requirements to systems serving fewer than 10000 persons, updated watershed control requirements to include Cryptosporidium as a concern for unfiltered systems, and addressed risk trade-offs with disinfection byproducts [17]. The 2006 rule required additional treatment for all unfiltered surface water systems and for filtered systems with significant levels of Cryptosporidium in their source waters [1820]. Treatment requirements are based on levels detected during monitoring. Systems serving at least 100000 people began monitoring in October 2006, and systems serving fewer than 10000 people began monitoring in October 2008. Compliance is required within three years after monitoring results were available, and systems are required to conduct additional monitoring six years after the initial monitoring to determine if source water conditions have changed significantly. The Filter Backwash Recycling Rule [21] helps ensure that recycle practices do not compromise the ability of treatment plants to remove pathogens, especially Cryptosporidium.

Coliforms in drinking water may indicate problems with water treatment (e.g., the system's treatment is inadequate to deal with source water contamination or is not performing properly) or problems in the distribution system. The Total Coliform Rule requires public water systems to monitor for indicators of fecal contamination and when coliforms are found, take corrective action and report violations to the state regulatory agency and the public $[22,23]$. Corrective actions include upgrades to water treatment or the distribution system and source water protection programs to prevent contamination. In 2007, EPA established an advisory committee to evaluate health risks associated with the degradation of water quality in the water distribution system and to suggest improvements to that rule [24]. Revisions to the rule were proposed in 2010 [25] and addressed these issues: cross-connections and backflow, mains repair and construction, storage facilities, pressure and intrusion, biofilm, nitrification, and contaminant accumulation.

The Ground Water Rule provides for increased protection against bacteria and viruses for systems that use ground water sources or that mix surface and ground water if the ground water is added to the distribution system without treatment [26, 27]. Periodic sanitary surveys are required to identify wells and springs that are susceptible to fecal contamination and to evaluate treatment technologies, operation, and management. Compliance monitoring is required to ensure that treatment reliably achieves 99.99 percent inactivation or removal of viruses.

\section{OUTBREAKS REPORTED IN PUBLIC WATER SYSTEMS}

The 733 outbreaks reported in public water systems resulted in 579582 cases of illness and 116 deaths (Table 2). Included among the 359 community system outbreaks is a single outbreak of 20

\begin{tabular}{|c|c|c|c|}
\hline Water system type & $\begin{array}{l}\text { Number of } \\
\text { outbreaks }\end{array}$ & $\begin{array}{c}\text { Cases of } \\
\text { illness }\end{array}$ & Deaths \\
\hline Community systems* & 359 & 521617 & 83 \\
\hline Non community systems & 353 & 57641 & 4 \\
\hline Unknown system type & 21 & 324 & 29 \\
\hline Total: public water systems & 733 & 579582 & 116 \\
\hline
\end{tabular}

cases associated with both community and individual water systems. Included among the 353 non-community system outbreaks is a single outbreak of 1450 cases associated with non-community and individual water systems. In these two outbreaks, wide spread contamination of ground water affected both public system and individual wells. For 21 public system outbreaks, insufficient information was available to classify the system as either community or non-community. Nineteen of the outbreaks with insufficient information were legionellosis outbreaks that occurred before 2001 and had just recently been added to the surveillance system; the other two outbreaks were associated with contamination at the point of water use.

Although community and non-community water systems reported a similar number of outbreaks, more illnesses occurred in community system outbreaks. Excluding the 403000 illnesses in the 1993 Milwaukee cryptosporidiosis outbreak $[30,31]$, outbreaks in community systems had twice the number of illnesses than outbreaks in non-community systems. The annual number of outbreaks in public water systems decreased throughout the 38-year period (Figure 1) as did their magnitude (Table 3 ). From a peak of 45 outbreaks in 1981, only 6 outbreaks were reported in 1998. Since 2001, annual reports ranged from 7 to 17 outbreaks. In recent years, outbreaks occurred primarily in small water systems with fewer cases of illness being reported. The median number of illnesses reported in public water system outbreaks during 20012008 was one-fourth that reported 1971-1980.

\section{Outbreak etiologies}

An etiology was identified for $414(56 \%)$ of the 733 outbreaks reported during 1971-2008 (Figure 2). Pathogens were identified in $341(46 \%)$ outbreaks; parasites and non-Legionella bacteria were the most frequently identified pathogens. Chemicals caused acute illness in $73(10 \%)$ outbreaks. Most frequently identified were high levels of copper associated with corrosive water and the overfeeding of fluoride or sodium hydroxide during water treatment. These three chemicals caused $26(36 \%), 12(16 \%)$, and 7 $(10 \%)$ of the chemical outbreaks, respectively. Other chemical contaminants included nitrate, herbicides, pesticides, and various types of oil products. An etiology was not determined in $319(44 \%)$ outbreaks 

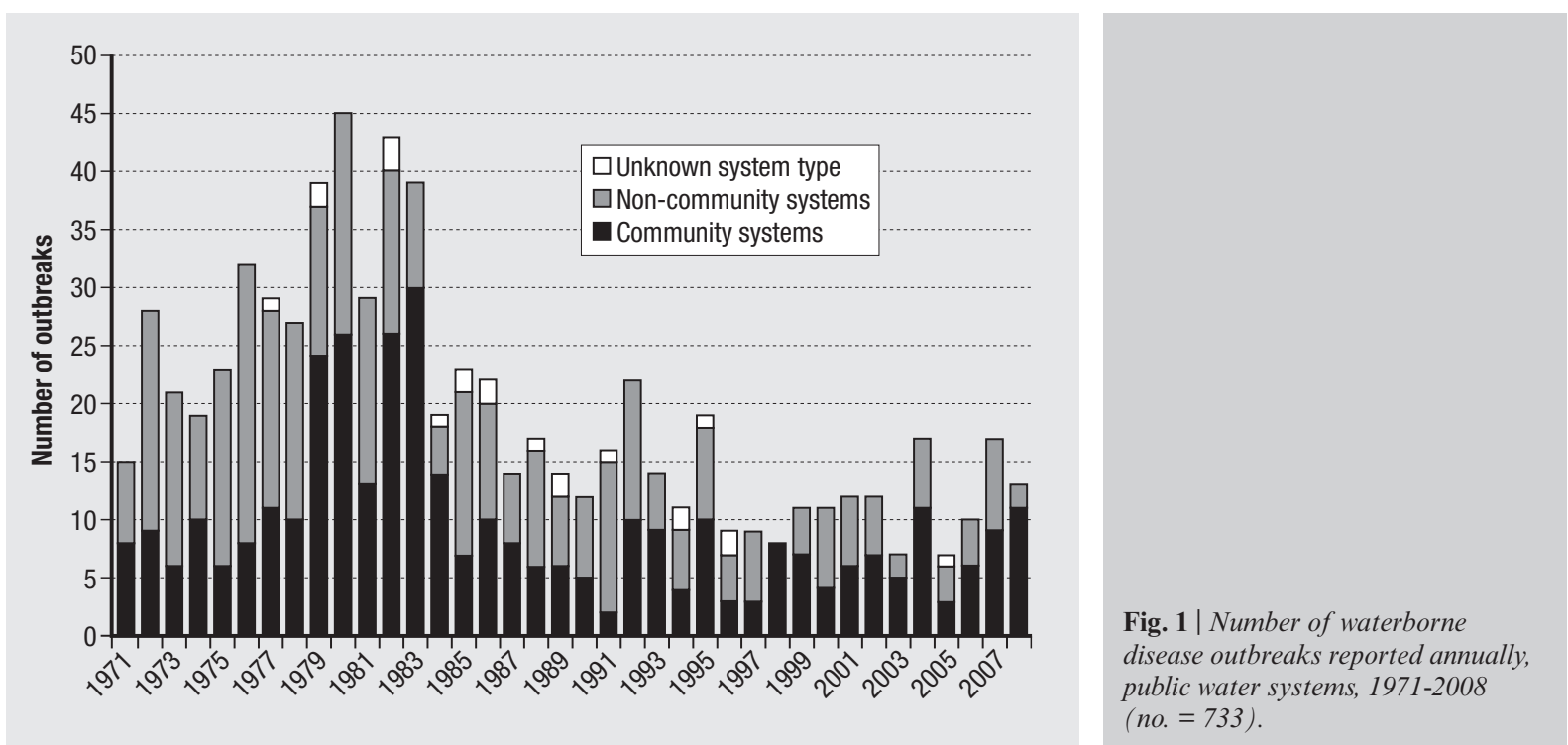

either because timely specimens were not collected and analyzed or because laboratory analyses could not identify an agent. In 317 of these outbreaks, 82869 cases of acute gastroenteritis were reported; two outbreaks resulted in 94 cases of severe watery diarrhea that lasted for months. The outbreaks of chronic gastroenteritis occurred in Illinois [32] in 1987 and in Oklahoma [33] in 1988.

\section{Parasites}

Giardia intestinalis was identified as the sole pathogen in $115(87 \%)$ of the parasitic outbreaks and was responsible for 28,161 cases. Cryptosporidium spp. were identified in $12(9 \%)$ parasitic outbreaks and caused 421301 cases; 403000 of these cases were attributed to C. hominis in the Milwaukee outbreak. Two outbreaks and 63 cases were attributed to Entamoeba histolytica, and two outbreaks and 103 cases were attributed to Cyclospora. An outbreak of C. cayetanensis, a rarely reported source of drinking water outbreaks in developed countries, occurred in Puerto Rico in 2008 [10]; a previous cyclosporiasis outbreak occurred in Chicago in 1990 [34]. The first association of a labora-

Table 3 | Trends in magnitude of waterborne disease outbreaks, public systems, 1971-2008

\begin{tabular}{|lccc|}
\hline Time period & \multicolumn{3}{c|}{ Cases of illnesses } \\
\hline & $\begin{array}{c}\text { Largest } \\
\text { outbreak }\end{array}$ & Mean & Median \\
\hline $1971-1980$ & 8000 & 277 & 50 \\
$1981-1990$ & 13000 & 272 & 37 \\
$1991-2000^{*}$ & 403000 & 3372 & 36 \\
2001-2008 & 1663 & 83 & 12 \\
\hline *Excluding the Milwaukee outbreak, the largest outbreak resulted in \\
9847 illnesses (mean =223).
\end{tabular}

tory-confirmed primary amebic meningoencephalitis with a drinking water system occurred in 2002; two previously healthy children died in Arizona [35]. The children lived in a neighborhood that received water from untreated wells. Naegleria fowleri was found in water from a storage tank connected to one of the wells, and the water tested positive for coliforms. In the remaining two parasitic outbreaks, G. intestinalis and Cryptosporidium parvum were identified in one, and $G$. intestinalis and E. histolytica were identified in the other.

\section{Non-Legionella bacteria}

Shigella spp., including S. sonnei and S. flexneri, were identified as the sole pathogens in $38(45 \%)$ of these outbreaks causing 9366 cases. S. typhi was responsible for two $(2 \%)$ outbreaks and 270 cases. Other Salmonella spp., including S. enterica serovar Typhimurium, were identified in $16(19 \%)$ outbreaks causing 4516 cases. Campylobacter spp., primarily C. jejuni, caused 19 (22\%) outbreaks and 5608 cases. Pathogenic Escherichia coli caused seven (9\%) outbreaks. One outbreak of $E$. coli O6:H16 resulted in 1000 cases, and five outbreaks of E. coli $\mathrm{O} 157: \mathrm{H} 7$ caused 1236 cases; a serotype was not identified in one outbreak of 1400 cases. One outbreak was caused by Pleisiomonas shigelloides (60 cases) and another by Providencia (55 cases). In the remaining four outbreaks, more than one bacterial pathogen was identified: $C$. jejuni \& Yersinia enterocolitica; $C$. jejuni \& $P$. shigelloides; E. coli $\mathrm{O} 157: \mathrm{H} 7$ \& C. jejuni; E. coli $\mathrm{O} 157$ : $\mathrm{H} 7$, E. coli $\mathrm{O} 145$ \& C. jejuni.

\section{Viruses}

Norovirus was identified as the sole pathogen in $38(66 \%)$ of the viral outbreaks and 14398 cases. Hepatitis A virus caused 19 (33\%) outbreaks and 600 cases. Rotavirus caused one (1\%) outbreak and 1761 cases. 

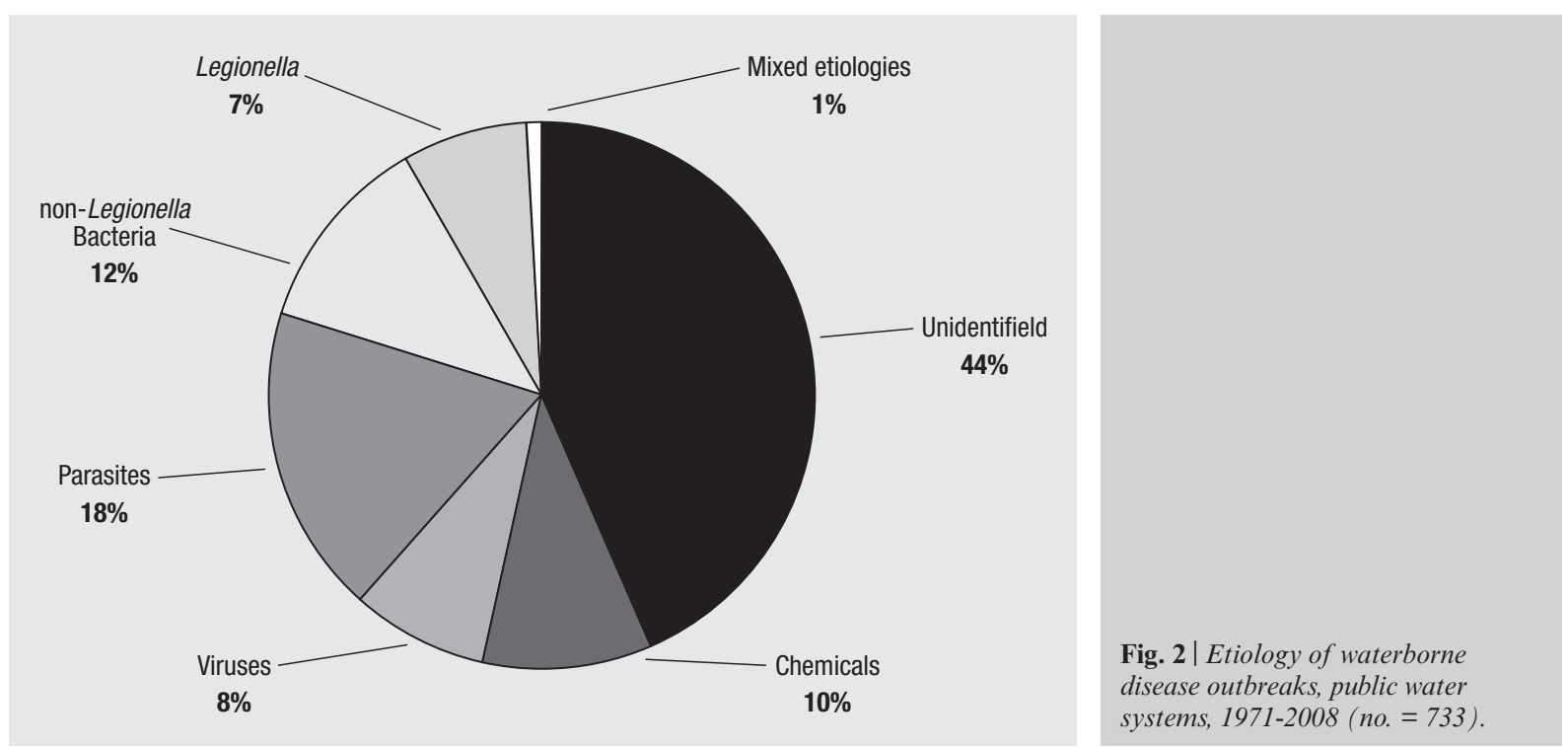

\section{Legionella}

The 54 Legionellosis outbreaks resulted in 472 cases. Illness was predominately due to $L$. pneumophilia serogroup 1 , but serogroups $3,4,5$, and 6 were also identified as were $L$. anisa, L. micdadei, and $L$. dumoffi.

\section{Mixed etiology}

Seven (1\%) outbreaks involved mixed agents. Non-Legionella bacteria and parasites were identified in four mixed-agent outbreaks: C. jejuni., C. lari, Cryptosporidium spp. \& Helicobacter canadensis; Salmonella spp. \& G. intestinalis; S. sonnei, Cryptosporidium spp., G. intestinalis \& Clostridium difficile; $C$. jejuni, Entamoeba spp. \& G. intestinalis. Two outbreaks involved bacteria and norovirus. Norovirus genogroups I and II and C. jejuni were identified in one outbreak. Norovirus genogroup I, Campylobacter spp., and Salmonella spp. were identified in the other. The remaining mixed-agent outbreak involved $C$. jejuni, norovirus, and $G$. intestinalis. Mixed-agent outbreaks were most reported frequently during 2001-2008.

\section{Trends}

This analysis considered the 364 pathogens identified in 341 outbreaks, 73 chemical outbreaks, and 319 outbreaks of undetermined etiology for a total of 756 etiologies. The relative importance of each etiology was determined by considering the proportion of that etiology (e.g., G. intestinalis, chemical etiology, undetermined etiology) among all of the etiologies reported during each of four specified time periods (Figure 3). Three 10-year periods and one 8year period were considered. Because outbreak statistics for 2009-2010 are likely to be available soon, eight years was chosen for the most recent period to allow for a convenient update of trends.

Most undetermined etiologies (57\%) occurred during the earliest time period of 1971-1980. The percentage of undetermined etiologies then declined. During 1981-1990 and 1991-2000, undetermined etiologies represented $44 \%$ and $39 \%$ of the etiologies, respectively, and during 2001-2008, only $9 \%$ of the etiologies were of undetermined etiology. The importance of chemical etiologies varied from a low of $6 \%$ during 1981-1990 to highs of $11 \%$ and 14\% during 1971-1980 and 1991-2000, respectively. During 2001-2008, 9\% of all etiologies were of a chemical etiology.

Reports of parasitic agents decreased whereas reports of viruses and Legionella increased (Figure 3). During 1971-2000, Legionella represented less than $5 \%$ of the etiologies, but during 2001-2008, Legionella represented $33 \%$ of all outbreak etiologies. Viruses represented $15 \%$ of etiologies during $2001-2008$ but only $6 \%$ to $8 \%$ of the etiologies during the preceding three decades. Norovirus represented $4 \%$ to $5 \%$ of all etiologies during 1971-2000, but during 2001-2008, norovirus was identified in $15 \%$ of the etiologies (Figure 3). Hepatitis A virus represented $4 \%$ or less of the etiologies during 1971-1990 but was identified in only one outbreak during 1991-2000 and none during 2001-2008. Rotavirus was identified in only one outbreak reported in 1981.

The importance of non-Legionella bacteria, as a group, has increased slightly. During 1971-1990, non-Legionella bacteria represented $11-12 \%$ of the etiologies. It has represented $16-18 \%$ of the etiologies since 1991. Before 2000, Campylobacter spp. represented less than $4 \%$ of the etiologies, but these bacteria were identified in $12 \%$ of the etiologies during 2001-2008. Pathogenic E. coli, primarily $0157: \mathrm{H} 7$, represented less than $1 \%$ of the etiologies before 1990 and $5 \%$ of etiologies during 1991-2000; however, only $2 \%$ of etiologies were due to E. coli during 2001-2008. Shigella spp., and Salmonella spp. have declined as important etiolo- 


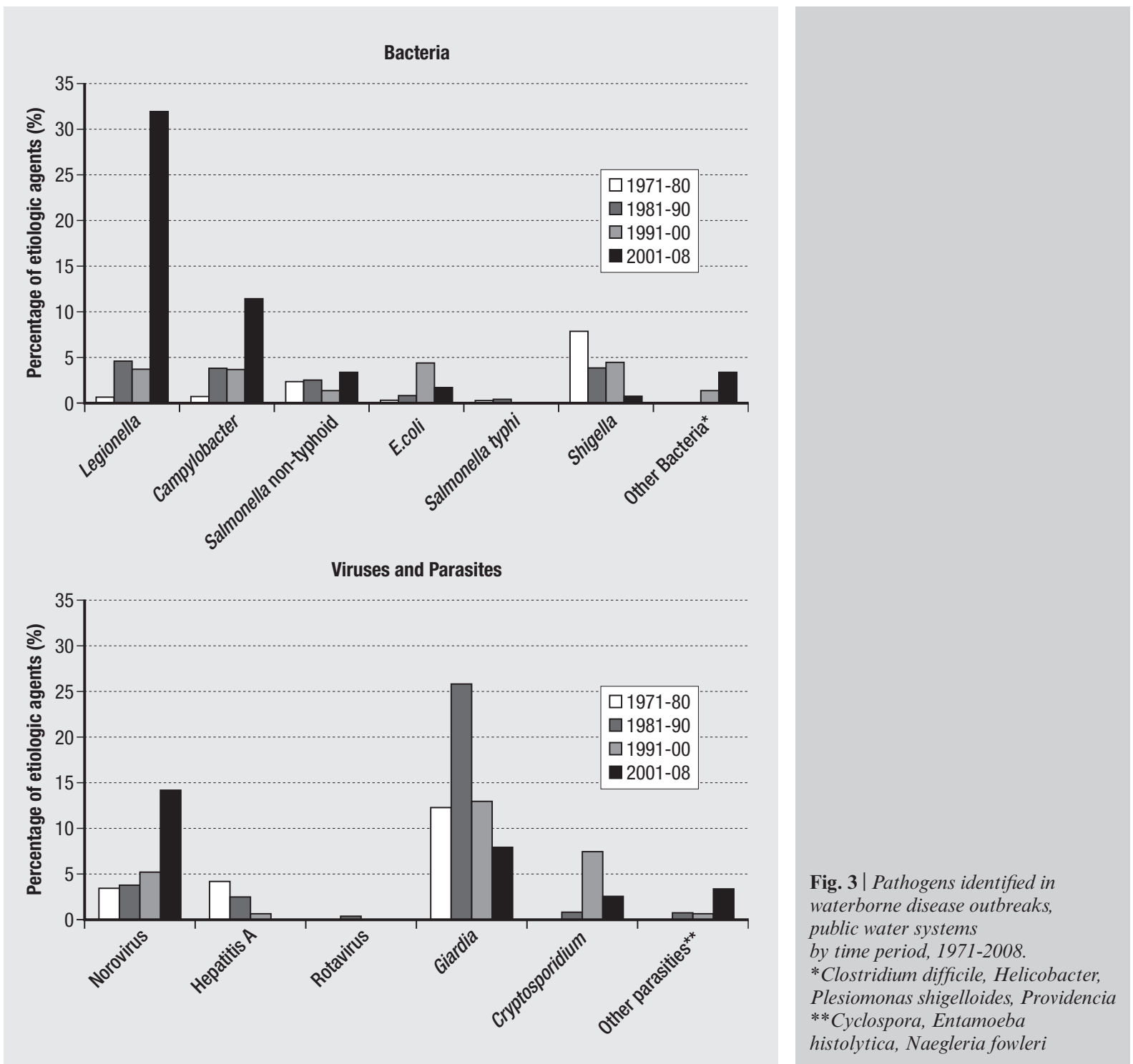

gies. During 1971-1980, Shigella spp. represented $8 \%$ of the etiologies, and Salmonella spp. represented $3 \%$ of the etiologies. Each represented only $1 \%$ of etiologies during 2001-2008. S. typhi was identified in only two outbreaks; one occurred in 1985 and the other in 1973.

Parasites have been an important etiologic agent throughout the 38 -year period but their importance has diminished (Figure 3 ).

Parasites represented $12 \%$ of the etiologies during $1971-1980$ increasing to $28 \%$ and $21 \%$ of the etiologies during 1981-1990 and 1991-2000, respectively. During 2001-2008, parasites represented $15 \%$ of the etiologies. G. intestinalis was identified in $12 \%, 26 \%$, and $13 \%$ of etiologies during 1971-1980, 1981-1990, and 1991-2000, respectively but only $8 \%$ of the etiologies during 2001-2008. Cryptosporidium spp. was identified in $8 \%$ of etiologies during 1991-2000 but only 3\% of the etiologies during 2001-2008.
Minor etiologic agents include $P$. shigelloides as the sole pathogen in one outbreak and one of two pathogens in another outbreak, both reported during 1991-2000. Y. enterocolitica and C. difficile were identified along with other agents in two separate outbreaks during 2001-8. Providencia, $N$. fowleri, and C. cayetanensis were also identified during 2001-2008, each causing one outbreak.

\section{Water system deficiencies}

Investigators identified 720 deficiencies during 1971-2008. A single water system deficiency or source of contamination was found in 685 outbreaks. Two deficiencies were identified in 16 outbreaks and three deficiencies were identified in one outbreak. In almost all $(94 \%)$ of the multiple-deficiency outbreaks, investigators found contamination from distribution system mains, storage facilities or premise plumbing (e.g., cross-connections or backflow) in addition to contamination from untreated or inadequately 
treated water. In 30 outbreaks, engineering and environmental information was inadequate to identify a deficiency.

The importance of each major deficiency category was considered for the entire 38-year period (Figure 4).

Inadequate or no treatment of ground water $(49 \%)$ and surface water $(20 \%)$ were the two most frequently reported deficiencies during the 38 -year period (Figure 4). Outbreaks were also caused by contamination of premise plumbing $(16 \%)$ and contamination of the distribution system $(10 \%)$. Premise plumbing refers to pipes and storage facilities within a building or house. The distribution system refers to pipes and storage facilities located outside a building or before entry to the property line. For community systems, the distribution system is under the control of the water utility. Contamination of water at its point of use (e.g., contaminated hose bibs or water storage containers) was a minor cause of outbreaks $(1 \%)$.

In the five of the outbreaks attributed to inadequate water treatment, investigators did not identify a water source in one outbreak and in four outbreaks both ground and surface water sources were used. When both the water source and deficiency are considered in an analysis, the four outbreaks in mixed-source systems were considered as surface water outbreaks. The one outbreak with an unidentified water source was included among those with insufficient information.

\section{Inadequate water treatment}

During 1971-2008, no treatment of ground water $(25 \%$; no. $=189)$ was reported more frequently than no treatment of surface water $(2 \%$; no. $=16)$. Information about the source of contamination or contributing factors was provided for 110 of the untreated ground water outbreaks. Investigators identified sewage overflow or seepage into the ground water in $44 \%$ of these 110 outbreaks. In an additional $18 \%$ of outbreaks, contaminants from unspecified sources entered wells developed in limestone or fissured rock aquifers. Ground water was contaminated during heavy rains and flooding in $22 \%$ of the outbreaks associated with untreated ground water. Improper construction and location too near a stream allowed contamination by surface water in $8 \%$ and $4 \%$ of these outbreaks, respectively. Chemical or pesticide contamination was identified in the remaining $4 \%$ of these outbreaks.

Inadequate treatment of ground water $(24 \%$; no. $=177)$ was also reported more frequently than inadequate treatment of surface water $(17 \%$; no. $=131)$. Details of the treatment deficiencies were available for 174 of these ground water outbreaks. Almost all of these outbreaks occurred in systems where disinfection was the only treatment for pathogens and were due to either inadequate $(40 \%)$ or interrupted $(49 \%)$ disinfection. Other treatment deficiencies for these 174 ground water outbreaks included inadequate control of chemical feed other than disinfection $(7 \%)$, inadequate control or operation of filtration facilities $(2 \%)$, and improper filter design $(1 \%)$.

Details of the treatment deficiencies were available for 130 of the 131 outbreaks caused by the inadequate treatment of surface water. Most deficiencies were associated with disinfection as the only treatment, either inadequate $(51 \%)$ or interrupted $(15 \%)$ disinfection. Other surface water treatment deficiencies included inadequate control of filtration $(26 \%)$, inadequate control of chemical feed other than disinfection $(4 \%)$, bypass of filtration $(2 \%)$, and inadequate or interrupted disinfection with filtration $(1 \%)$.
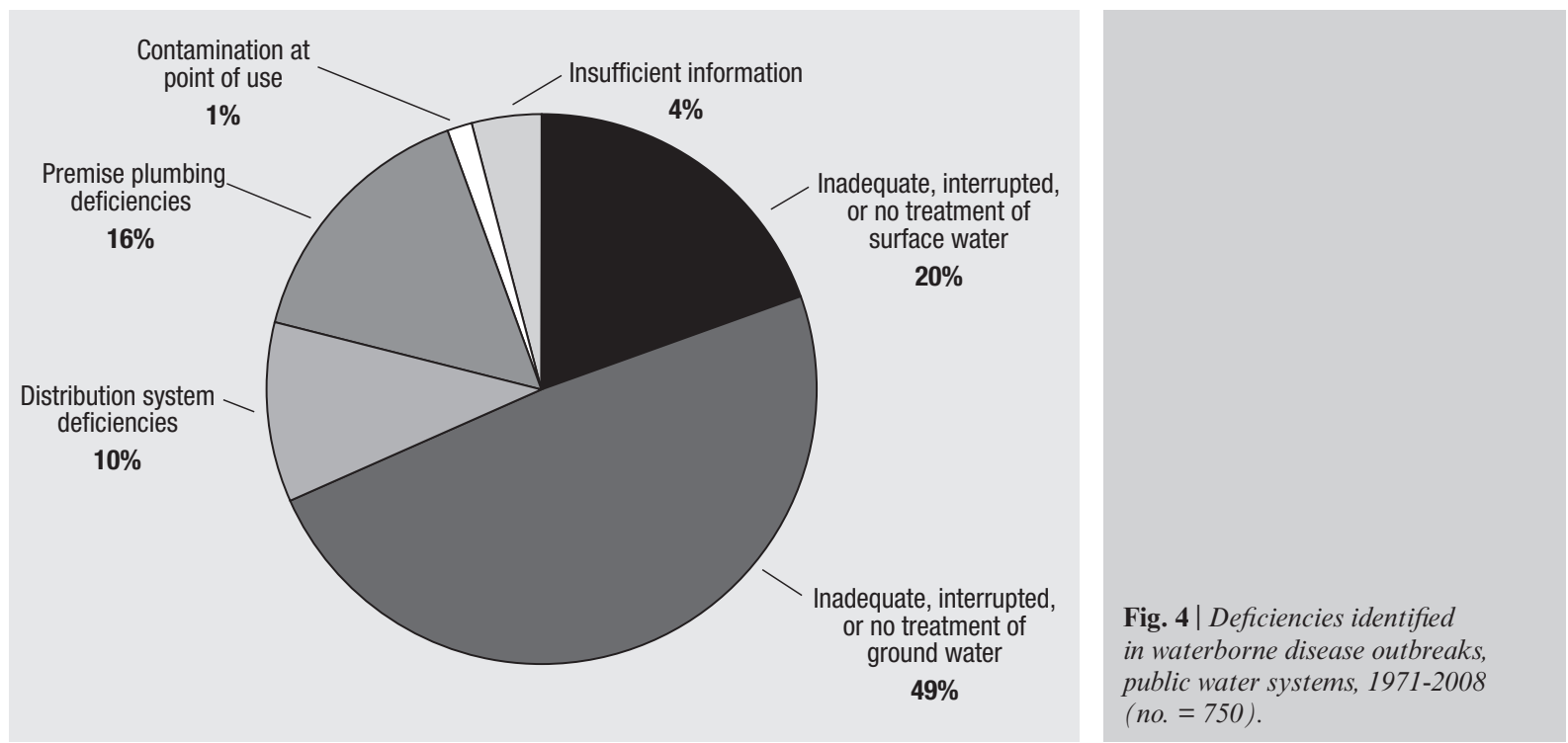


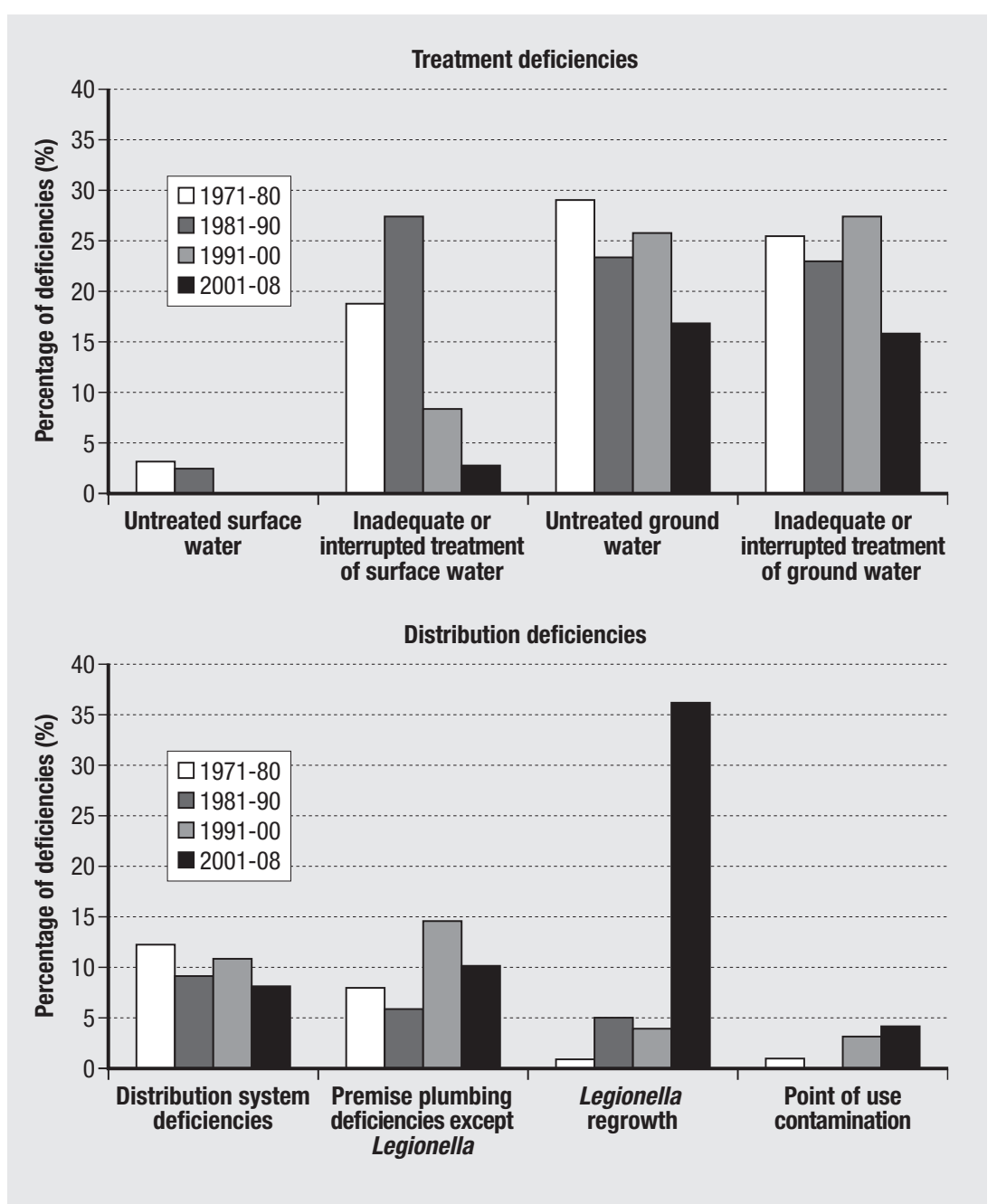

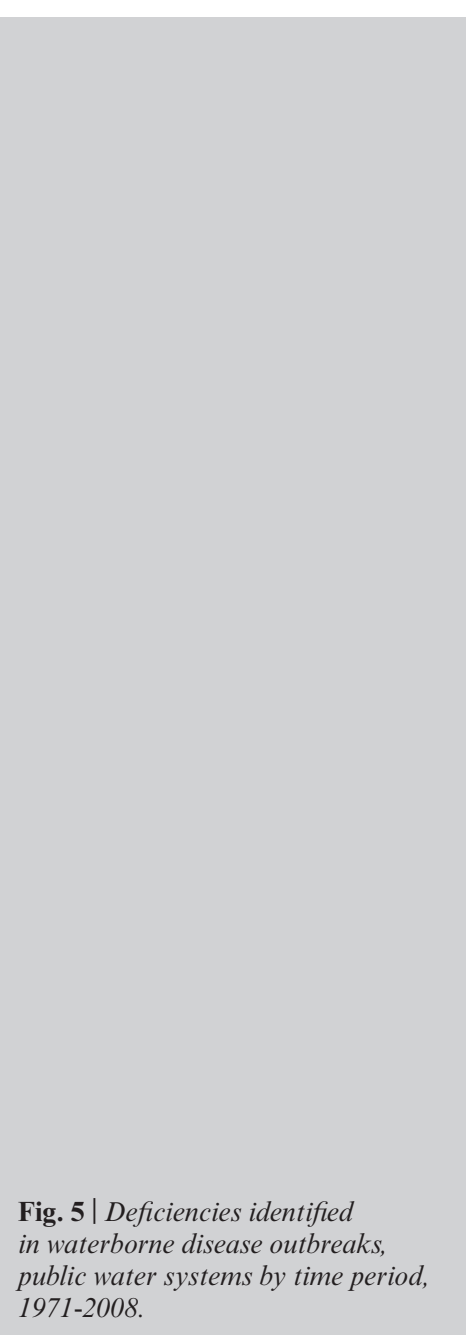

\section{Distribution system and premise plumbing deficiencies}

Most (55\%) distribution system deficiencies during 1971-2008 were due to cross-connections or backflow events. Other distribution system deficiencies included contamination of storage facilities $(19 \%)$, broken or leaking water mains $(15 \%)$, and contamination of mains during construction, repair, or flushing $(9 \%)$. Legionella regrowth was identified in $47 \%$ of the outbreaks where premise plumbing deficiencies were reported. Also identified were: cross-connections or backflow events $(30 \%)$, corrosion byproducts of plumbing systems or drink-mix machines $(20 \%)$, and contamination of service lines or in-building storage facilities (3\%).

\section{Trends}

The relative importance of each deficiency was determined in the same manner and for each of the same four time periods considered for etiologies. The analysis considered 750 deficiencies, which includes the 30 outbreaks with unidentified deficiencies (Figure 5). Unidentified deficiencies represented $2 \%$ to $4 \%$ of the deficiencies reported during 1971-1990 and $6 \%$ of the deficiencies reported during 1991-2008.
The majority $(55 \%)$ of deficiencies during 19711980 involved the use of contaminated ground water that received either no treatment $(29 \%)$ or inadequate treatment $(26 \%)$. The use of untreated ground water continued to be an important deficiency being responsible for $24 \%$ of deficiencies during 1981-89, $26 \%$ during 1991-2000, and 17\% during 2001-2008. The inadequate treatment of ground water also continued to be important; it was responsible for $23 \%$ of deficiencies during 1981-90, 28\% during 19912000 , and $16 \%$ during 2001-2008.

The use of untreated contaminated surface water was responsible for less than 3\% of the deficiencies during 1971-1990. Afterwards, the EPA regulations required treatment for surface water sources. The inadequate treatment of surface water was responsible for $19 \%$ and $27 \%$ of all deficiencies during 1971-1980 and 1981-1990, respectively. As more attention was given to surface water treatment, the importance of this deficiency was diminished; only $8 \%$ and $3 \%$ of the deficiencies were due to the inadequate treatment of surface water during 1991-2000 and 2001-2008, respectively.

Premise plumbing deficiencies have increased in importance, and distribution system contamination con- 
Table 4 | Percentage of etiologic agents responsible for waterborne disease outbreaks, public systems by time period, 1971-2008

\begin{tabular}{|lcccc|}
\hline Etiology & $\begin{array}{r}\mathbf{1 9 7 1 - 1 9 8 0} \\
\text { (no. = 278) }\end{array}$ & $\begin{array}{c}\mathbf{1 9 8 1 - 1 9 9 0} \\
\text { (no. = 232) }\end{array}$ & $\begin{array}{c}\mathbf{1 9 9 1 - 2 0 0 0} \\
\text { (no. = 128) }\end{array}$ & $\begin{array}{c}\mathbf{2 0 0 1 - 2 0 0 8} \\
\text { (no. = 95) }\end{array}$ \\
\hline Legionella & $1 \%$ & $5 \%$ & $4 \%$ & $38 \%$ \\
non-Legionella bacteria & $12 \%$ & $11 \%$ & $15 \%$ & $11 \%$ \\
Viruses & $8 \%$ & $7 \%$ & $6 \%$ & $14 \%$ \\
Parasites & $12 \%$ & $27 \%$ & $20 \%$ & $11 \%$ \\
Chemicals & $11 \%$ & $6 \%$ & $14 \%$ & $10 \%$ \\
Unidentified etiology & $56 \%$ & $44 \%$ & $40 \%$ & $10 \%$ \\
Mixed etiology & 0 & $<1 \%$ & $1 \%$ & $6 \%$ \\
total & $100 \%$ & $100 \%$ & $100 \%$ & $100 \%$
\end{tabular}

tinues to be important. The contamination of premise plumbing with Legionella was responsible for $36 \%$ of the deficiencies during 2001-2008. During the same time period, other pathogens or chemicals were responsible $10 \%$ of the deficiencies. Contamination of distribution system pipes and storage facilities was identified in $8 \%$ of the deficiencies during 2001-2008 only slightly less than the $9 \%$ to $12 \%$ in previous time periods.

\section{Outbreak risks}

Although the relative importance of an outbreak deficiency during each decade is informative, this measure does not take into account changes that may have occurred in water sources and treatment. This is important when assessing risks associated with the treatment for surface water sources. In 1986, information became available about the number of public water systems that used surface water and the type of treatment that was employed [22]. At that time there were 9527 public systems that used surface water. The number increased to 13608 systems in 1998 [36] and 14371 systems in 2010 [12]. Outbreak rates computed for the period 1971-1985 showed that community water systems with disinfection as the only treatment for surface water had an almost 8-fold higher outbreak risk than systems with both disinfection and filtration [37]. Outbreak risks for systems using untreated surface water were similarly high.

For this article, I computed outbreak risks for public systems using surface water during 1981-2008 using water system inventory information available from the EPA [22, 36, 38]. These risks consider only infectious disease outbreaks; chemical outbreaks were excluded from the analysis. Both the number and risk of out- breaks declined for all three types of surface water systems (Table 5). Outbreak risks for public systems using untreated or disinfected-only surface water during 1981-1990 were 5 to 6-fold higher than risks for systems using filtered and disinfected surface water. During 1991-2000, the outbreak risk for disinfected-only surface water systems declined considerably but was still almost 2-fold higher than for filtered systems. The outbreak risk for filtered surface water systems decreased to about half of the risk seen during 1991-2000.

During 1981-1990, six outbreaks were reported in public systems using untreated surface water systems and 39 outbreaks in systems providing only disinfection. The most recent outbreak associated with untreated surface water was reported in 1990. There were five outbreaks associated with unfiltered, disinfected surface water systems during 1991-2000 and no outbreaks have been reported in disinfected only surface water systems since 1997. Outbreaks in filtered, disinfected surface water systems decreased from 22 outbreaks during 1981-1990 to five outbreaks during 1991-2000 and three outbreaks during 2001-2008. Two of the three outbreaks associated with filtered systems since 2001 occurred in small non-community systems that provided water to campgrounds and resulted in 60 illnesses. The third outbreak of 1663 cases of gastrointestinal illness occurred in a community water system supplied by surface water conventionally treated with coagulation, settling, filtration, and disinfection [10]. Investigators identified numerous deficiencies in the operation and maintenance of disinfection and filtration facilities including the recycling of untreated filter backwash water. Filter

Table 5 | Outbreak risks associated with inadequate treatment, public water systems using surface water, 1991-2008

Infectious disease outbreaks per year per 10000 systems

\begin{tabular}{|lccc|}
\hline Water source and treatment & $\mathbf{1 9 8 1 - 1 9 9 0}$ & $\mathbf{1 9 9 1 - 2 0 0 0}$ & $\mathbf{2 0 0 1 - 2 0 0 8}$ \\
\hline Surface water, untreated & 18.99 & 0 & 0 \\
Surface water, disinfection only & 16.05 & 1.08 & 0 \\
Surface water, filtration and disinfection & 3.18 & 0.56 & 0.31
\end{tabular}


performance was adversely affected when backwash water was routed directly to the treatment flow bypassing the recovery basin and disinfection.

Less attention has been paid to outbreak risks in ground water systems, but it is also important to consider these because public systems using ground water have decreased from 156768 in 1998 [36] to 138527 in 2010 [12]. The number of infectious disease outbreaks associated with untreated and inadequately treated ground water also decreased from 61 during 1991-2000 to 30 during 2001-2008 with approximately half of the outbreaks in untreated ground water systems. However, the outbreak risks for untreated ground water systems remained relatively stable with rates of 0.29 and 0.21 outbreaks per year per 10000 systems in 1991-2000 and 20012008, respectively. Outbreak risks associated with treated ground water systems declined slightly during the same time periods from 0.68 to 0.40 outbreaks per year per 10000 systems. All except three outbreaks during the past 18 years were due to inadequate or interrupted disinfection as the only treatment for ground water. Three outbreaks occurred in filtered and disinfected ground water systems; one in 1991-2000 and two in 2001-2008.

\section{DISCUSSION}

The US waterborne disease outbreak surveillance system has largely been successful because of the continued cooperation of public health professionals at the EPA, CDC and various state agencies. This cooperation is necessary because the responsibility for establishing national drinking water regulations and conducting the accompanying health effects and water treatment research resides within the EPA, whereas the responsibility for disease surveillance resides within CDC. In addition, most states have a similar arrangement where environmental protection agencies are responsible for ensuring the safety of drinking water while state public health agencies are responsible for disease surveillance and outbreak investigation. Even when both of these responsibilities reside within the same state agency, several different bureaus may be involved. In addition, outbreak investigation requires professionals with differing technical expertise, some of which may be provided from sources outside the government. Continued leadership at the federal and state levels is necessary to ensure that outbreaks are detected, investigated, and reported.

This review of the surveillance statistics describes the causes of outbreaks associated with public water systems and the changes that have occurred in the etiologic agents, risk factors, and major deficiencies during the past 38 years. Increased reports of outbreaks in the early 1980s emphasized that microbial contaminants remained a health-risk challenge for suppliers of drinking water. Analyses of the causes of these outbreaks helped focus attention on water system deficiencies, especially the high risk of out- breaks associated with unfiltered surface water systems, and this provided the stimulus for the research that formed the basis for water system improvements. Research included studies that demonstrated the removal of Giardia cysts and Cryptosporidium oocysts by water filtration and inactivation of parasites, viruses, and bacteria by disinfectants [39, 40]. All of the EPA rules to reduce microbial risks contained a discussion of the waterborne outbreak statistics that showed the need for intervention as well as the remedies suggested by the research studies. Although surveillance statistics have provided important information which is summarized below, readers should be aware that they represent only a portion of the incidence of outbreaks. Not all outbreaks are recognized or reported [41] and outbreak statistics do not reflect the burden of endemic waterborne illness [42, 43].

\section{Increased identification of etiologic agents}

The decreased proportion of outbreaks associated with undetermined etiologies is likely due to newly developed and improved laboratory diagnostic tools to identify etiologic agents in clinical specimens and water samples (e.g., detection of norovirus). A contributing factor may be early outbreak detection which allows for a more timely collection of clinical specimens and water samples. Both timely collection and improved laboratory analyses are important to identify waterborne pathogens of emerging importance. The continued collaboration of state public health and drinking water regulatory agencies is required to ensure the early recognition of an outbreak and its investigation. It is especially important that prior arrangements are made to ensure adequate laboratory support during outbreak investigations.

\section{Decreased reports of outbreaks in public systems}

The number of outbreaks associated with public water systems has decreased, especially since the peak reporting in the early 1980 s. This decrease is likely the result of national drinking water regulations and improved water system management, operation, and treatment practices. Improvements were largely due to the cooperative efforts of the EPA, public water systems, the American Water Works Association, and the Association of State Drinking Water Administrators. An example of cooperative efforts is the Partnership for Safe Water, whose objective is to improve water plant performance, emphasizing the importance of design, operation, and monitoring of filtration and disinfection [44].

\section{Decreased importance}

\section{of inadequately treated surface water}

There has been a decrease in both the proportion of deficiencies and outbreak risks associated with inadequately treated surface water in public systems. The decrease is associated with the promulgation 
of EPA regulations and water treatment improvements to reduce risks in surface water sources from Giardia and Cryptosporidium. During 2001-2008, no outbreaks were reported in unfiltered surface water. The three outbreaks associated with filtered water systems during the same period, emphasize the importance of proper operation and maintenance of disinfection and filtration processes, especially for small public systems.

\section{Continued importance of inadequately treated ground water}

There has been no significant reduction in outbreak risks or the proportion of outbreaks associated with untreated or treated ground water. The inadequate or no treatment of ground water accounted for one-third of all deficiencies reported during 2001-2008. Sixteen outbreaks were associated with public systems that provided treatment of ground water during the past eight years. The over feeding of sodium hydroxide was responsible for three outbreaks. Eleven outbreaks occurred in disinfected ground water systems; in six outbreaks, disinfection was interrupted and in five disinfection levels were inadequate.

In one of two outbreaks where filtration was provided, the filter was not designed to remove cysts and oocysts. The second outbreak involved a spring under the direct influence of surface water. After installing a slow sand filter, inadequate time was allowed for formation of a schmutzdecke biological layer on the surface of the filter, and this resulted in poor removal of pathogens. These ground water outbreaks are a reminder not only of the potential for contamination of source water but also the need for increased attention to design of treatment facilities and their proper operation. When provided, treatment should be adequate to cope with anticipated source water contamination and operated without interruption. Implementation of EPA's Ground Water Rule [26, 27] should help decrease risks for ground water systems.

\section{Increased importance}

\section{of premise plumbing contamination}

The increased proportion of outbreaks associated with premise plumbing deficiencies is largely due to Legionella regrowth. Legionella can grow within premise plumbing water pipes, and prevention of outbreaks requires careful attention to maintaining water systems according to published guidelines [45]. During 2001-2008, acute respiratory illness was reported in $38 \%$ of the outbreaks, all associated with the amplification and dissemination of Legionella through premise plumbing, pipes, and storage infrastructure. Two-thirds of the outbreaks occurred in hospitals, nursing homes, and other health care settings, demonstrating the ability of Legionella to colonize the biofilms frequently found inside the large, complex plumbing systems of these facilities.

\section{Continued importance of distribution system contamination}

The proportion of outbreaks associated with distribution system deficiencies is similar to premise plumbing deficiencies when legionellosis outbreaks are excluded from the analysis. Increased attention to this problem is warranted because of the continuing occurrence of outbreaks as well as studies that show the potential for contamination through low pressure events [45] and need for infrastructure improvements $[46,47]$.

\section{CONCLUSIONS}

This review illustrates the importance of a waterborne disease outbreak surveillance system.

Surveillance statistics collected during the past 38 years in the United States have helped identify important water system deficiencies, guiding prevention efforts at the national, state, and local levels.

Surveillance statistics have also demonstrated the effectiveness of prevention efforts. Waterborne outbreak risks associated with the treatment of surface water have declined significantly.

However, outbreaks due to other water system deficiencies still occur, and continued surveillance is warranted. Collaboration must be maintained among current government and nongovernment participants for an effective US surveillance system.

Although the CDC has the primary responsibility for waterborne outbreak surveillance, the EPA should continue to be an active partner because of its regulatory and research responsibilities.

Timely knowledge about the etiologies and causes of waterborne outbreaks has been, and will continue to be, important in establishing research priorities and recommending preventive measures.

\section{Acknowledgements}

This article could not have been written without contributions from the state and territorial waterborne disease surveillance coordinators, drinking water administrators, epidemiologists, and other professionals who have investigated outbreaks and reported them to the surveillance system. I would like to pay tribute to two friends and colleagues, Lee McCabe and Rebecca Calderon, with whom I have collaborated in numerous reports on the causes of waterborne outbreaks. Both recognized the importance of the systematic collection of waterborne outbreak statistics. Lee McCabe was largely responsible for originating the EPA-CDC partnership and maintaining it while he was at EPA. Rebecca Calderon continued EPA's active participation in the surveillance system from 1993 to 2008. A special thanks to Nate B. Craun who assisted me with this article.

\section{Conflict of interest statement}

There are no potential conflicts of interest or any financial or personal relationships with other people or organizations that could inappropriately bias conduct and findings of this study.

Submitted on invitation

Accepted on 24 September 2012. 


\section{References}

1. Gorman A, Wolman A. Water-borne outbreaks in the United States and Canada and their significance. $J \mathrm{Am}$ Water Works Assoc 1939;31:225-75.

2. Eliassen R, Cummings RH. Analysis of waterborne outbreaks, 1938-45. J Am Water Works Assoc 1948;40:509-28.

3. Weibel S, Dixon FR, Weidner RB, McCabe LJ. Waterborne disease outbreaks, 1946-60. J Am Water Works Assoc 1964; 56:947-58.

4. Craun G, McCabe LJ. Review of the causes of waterbornedisease outbreaks. J Am Water Works Assoc 1973;65:74-84.

5. Craun GF. Statistics of waterborne outbreaks in the US (1920-1980). In: Craun GF (Ed.). Waterborne diseases in the United States. Boca Raton, FL: CRC Press, Inc; 1986.

6. Craun GF, Brunkard JM, Yoder JS, et al. Causes of outbreaks associated with drinking water in the United States from 1971 to 2006. Clin Microbiol Rev 2010;23:507-28. http://dx.doi.org/10.1128/CMR.00077-09.

7. Hearings before the Subcommittee on Public Health and Environment, Safe Drinking Water Act, 93 ${ }^{\text {rd }}$ Congress, March 8-9, 1973.

8. Karalekas Jr PC, Taylor FB. Regulations and surveillance. In: Craun GF (Ed.). Waterborne diseases in the United States. Boca Raton, FL: CRC Press, Inc; 1986.

9. Environmental Protection Agency. Water programs: national interim primary drinking water regulations. Federal Register 1975;59566-74.

10. Brunkard JM, Ailes E, Roberts VA, Hill V, Hilborn ED, Craun GF, et al. Surveillance for waterborne disease outbreaks associated with drinking water: United States, 2007-2008. MMWR 2011;60(SS-12):38-68.

11. Hlavsa MC, Roberts VA, Anderson AR, Hill V, Kalher AM, et al. Surveillance for waterborne disease outbreaks and other health events associated with recreational water, United States, 2007-2008. MMWR 2011;60(SS-12):1-32.

12. Environmental Protection Agency. Fiscal year 2010 drinking water and ground water statistics. Washington: Office of Ground Water and Drinking Water; 2011 updated February 2012 (EPA 817K11001).

13. Pontius F, Roberson JA. The current regulatory agenda. J Am Water Works Assoc 1994;86(2):54-63.

14. Pontius F. Implementing the 1996 SDWA amendments. J Am Water Works Assoc 1997;89(3):18-36.

15. Environmental Protection Agency. Drinking water, national primary drinking water regulations, filtration, disinfection, turbidity, Giardia lamblia, viruses, Legionella, and heterotrophic bacteria; final rule. Federal Register 1989:27486-541.

16. Environmental Protection Agency. National primary drinking water regulations: interim enhanced surface water treatment; final rule. Federal Register 1998;63:69478-521.

17. Environmental Protection Agency. National primary drinking water regulations: long term 1 enhanced surface water treatment rule; final rule. Federal Register 2002;67:1812-44.

18. Environmental Protection Agency. National primary drinking water regulations: monitoring requirements for public drinking water supplies: Cryptosporidium, Giardia, viruses, disinfection byproducts, water treatment plant data and other information requirements; final rule. Federal Register 1996;61:24353-88.

19. Environmental Protection Agency. National primary drinking water regulations: long term 2 enhanced surface water treatment rule. Federal Register 2006;71:653-702.

20. Environmental Protection Agency. National primary drinking water regulations: stage 2 disinfectants and disin- fection byproducts rule. Federal Register 2006;71:387-493.

21. Environmental Protection Agency. National primary drinking water regulations: filter backwash recycling rule. Federal Register 2001;66:31086-105.

22. Environmental Protection Agency. Drinking water; national primary drinking water regulations; total coliforms (including fecal coliforms and E. coli); final rule. Federal Register 1989;54:27544-68.

23. Environmental Protection Agency. Drinking water; national primary drinking water regulations; total coliforms; corrections and technical amendments; final rule. Federal Register 1990;55:25064-5.

24. Environmental Protection Agency. Establishment of the total coliform rule distribution system advisory committee. Federal Register 2007;72:35869-70.

25. Environmental Protection Agency. National primary drinking water regulations: revisions to the total coliform rule. Federal Register 2010;75 FR 40926-1016.

26. Environmental Protection Agency. National primary drinking water regulations: ground water rule; proposed rule. Federal Register 2000;65:30194-274.

27. Environmental Protection Agency. National primary drinking water regulations: ground water rule. Federal Register 2006;19:65573-660.

28. Environmental Protection Agency. Announcement of the drinking water contaminant candidate list; notice. Federal Register 1998;63:10274-87.

29. Environmental Protection Agency. Drinking water contaminant candidate list 3; final notice. Federal Register 2009; 74:51850-62.

30. MacKenzie WR, Hoxie NJ, Proctor ME, Gradus MS Blair $\mathrm{KA}$, et al. A massive outbreak in Milwaukee of Cryptosporidium infection transmitted through the public water supply. New Engl J Med 1994;331(3):161-7.

31. Hoxie NJ, Davis JP, Vergeront JM, Nashold RD, Blair KA. Cryptosporidiosis-associated mortality following a massive waterborne outbreak in Milwaukee. Am J Public Health 1998;87:2032-5. http://dx.doi.org/10.2105/AJPH.87.12.2032.

32. Parsonnet J, Trock SC, Bopp CA, Wood CJ, Addiss DG, et al. Chronic diarrhea associated with drinking untreated water. Ann Intern Med 1989;110:985-991.

33. Harkess JR, Reiner K, Pendergraph D, Krisher K, Istre GR. Chronic diarrhea syndrome. An epidemic and endemic problem in Oklahoma. EIS Conference Abstracts. Atlanta: CDC; 1990. p. 19.

34. Huang P, Weber JT, Sosin DM, et al. The first reported outbreak of diarrheal illness associated with Cyclospora in the United States. Ann Intern Med 1995;123:409-14.

35. Blackburn BG, Craun GF, Yoder JS, Hill V, Calderon RL, Chen N, Lee SH Levy DA Beach MJ. Surveillance for waterborne-disease outbreaks associated with drinking water. United States, 2001-2002. MMWR 2004;53(SS-8):23-45.

36. Environmental Protection Agency. Factoids: drinking water and ground water statistics for 1998. Available from: www. epa.gov/ogwdw/databases/pdfs/data_factoids_1998.pdf.

37. Craun GF. Surface water supplies and health. J Am Water Works Assoc 1988; 80(2):40-52.

38. Environmental Protection Agency. Factoids: drinking water and ground water statistics for 2008. Available from: www. epa.gov/ogwdw000/databases/pdfs/data_factoids_2008.pdf.

39. Logsdon GS, Symons JM, Hoye Jr RL, Arozarena MM. Alternative filtration methods for removal of Giardia Cysts and Cyst Models. J Am Water Works Assoc 1981;73(2):111-8. 
40. Hoff JC. Inactivation of microbial agents by chemical disinfectants. Washington: EPA; 1986 (EPA/600/2-86/067).

41. Harter L, Frost F, Vogt R, Little A, Hopkins R, Gaspard B, Lippy L. A three-state study of waterborne disease surveillance techniques. Am J Pub Health 1985;75(11):1327-28. http://dx.doi.org/10.2105/AJPH.75.11.1327.

42. Colford JM, Roy SL, Beach MJ, Hightower A, Shaw SE, Wade TJ. A review of household drinking water intervention trials and an approach to the estimation of endemic waterborne gastroenteritis in the United States. J Water Health 2006:4(Suppl. 2):71-88. http://dx.doi.org/10.2166/wh.2006.018

43. Messner MS, Shaw S, Regli S, Rotert K, Blank V, Soller J. An approach for developing a national estimate of waterborne disease due to drinking water and a national estimate model application. $J$ Water Health 2006;4(Suppl 2):201-40. http://dx.doi.org/10.2166/wh.2006.024
44. American Water Works Association. Partnership for safe water. Available from: www.awwa.org.

45. American Society of Heating, Refrigerating and AirConditioning Engineers. ASHRAE Guideline 12-2000. Minimizing the risk of legionellosis associated with building water systems. Atlanta: American Society of Heating, Refrigerating and Air-Conditioning Engineers, Inc.; 2000

46. LeChevallier MW, Gullick RW, Karim MR, Friedman M, Funk JE. The potential for health risks from intrusion of contaminants into the distribution system from pressure transients. $J$ Water Health 2003;1:3-14.

47. Environmental Protection Agency. Drinking water infrastructure needs survey and assessment. Washington: Office of Water; 2009 (EPA 816-R-09-001). Availabre from: www.epa.gov/safewater/needssurvey/pdfs/2007/report_ needssurvey_2007.pdf. 